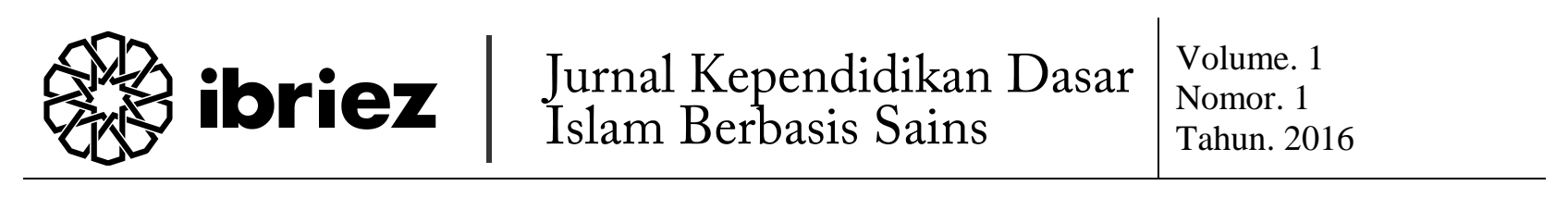

\title{
Komunikasi Edukatif dalam Perspektif Alquran (Analisis Kisah Musa)
}

\author{
Khori Robihatul Musayadah, Evi Mu'afiah \\ Tarbiyah STAIN Ponorogo \\ khoiri.robihatul@yahoo.co.id
}

\begin{abstract}
Abstrak
Komunikasi merupakan salah satu hal yang sangat diperlukan dalam kehidupan. Komunikasi memiliki banyak fungsi, salah satunya adalah fungsi edukasi atau pendidikan. Nabi Musa merupakan salah satu Rasul Allah yang dapat dijadikan tauladan oleh seorang pendidik dalam melaksanakan pembelajaran. Adapun metode yang digunakan adalah content analysis dan penelitian ini merupakan jenis penelitian library research dengan pendekatan Historis. Adapun hasil dari penelitian ini adalah (1) komunikasi yang terjadi dalam kisah Musa merupakan komunikasi edukatif yang dapat dilihat dari peran Nabi Musa sebagai seorang edukator dan tujuan komunikasi tersebut yaitu mengubah pengetahuan Bani Israil tentang ketauhidan; (2) tahapan-tahapan yang terdapat dalam strategi komu-nikasi edukatif dalam kisah Musa adalah menemukan masalah Bani Israil, menentukan tujuan, merencanakan komunikasi, menyampaikan risalah, Umpan balik, dan evaluasi beru-pa cobaan; (3) tahapan strategi komunikasi edukatif dalam kisah Musa merupakan gabung-an dari tahapan strategi komunikasi Cultid dan Center, Philip Lesly, John Middleton, lima langkah, dan advokasi.
\end{abstract}

Kata kunci: Komunikasi Edukatif; Kisah Musa dalam Al-Qur'an

\section{A. PENDAHULUAN}

Manusia merupakan makhluk sosi-

al. Manusia berperan sebagai individu yang tidak dapat hidup sendiri, tetapi membu-tuhkan orang lain. Jadi, manusia harus menjalin hubungan atau relasi dengan orang lain. Dalam menjalin relasi dengan orang lain, manusia membutuhkan sebuah media. Media inilah yang dinamakan komu-nikasi. ${ }^{1} \quad$ Dalam kehidupan masyarakat, ko-munikasi mempunyai peranan yang cukup besar karena dengan komunikasi akan ter-cipta suasana lingkungan yang mengarah kepada integritas masyarakat serta nilainilai masyarakat akan dapat dikokohkan

\footnotetext{
${ }^{1}$ Suranto AW, Komunikasi Interpersonal (Yogyakarta: Graham Ilmu, 2011), 27.
} 
apabila masyarakat dapat berkomunikasi dengan baik. ${ }^{2}$

Komunikasi yang baik akan menciptakan lingkungan masyarakat yang kon-dusif dan dapat mewujudkan hubungan yang positif di antara masyarakat serta nilai-nilai yang ada di dalam masyarakat dapat diterima dan diterapkan lebih efektif.

Komunikasi dapat dilakukan secara verbal (lisan) dan nonverbal. Kedua cara komunikasi tersebut memiliki kelemahan dan kelebihan. Komunikasi yang dilakukan secara lisan dapat memberikan keuntungan, salah satunya adalah memberikan kesempatan kepada pengirim untuk mengen-dalikan situasi. Apabila kita memiliki ke-mampuan bicara yang baik, maka informasi yang kita sampaikan akan dapat diterima dengan efektif dan jelas oleh penerima pesan. ${ }^{3}$

Komunikasi mempunyai banyak fungsi.Salah satunya adalah fungsi edukatif atau fungsi pendidikan. Dalam pembela-jaran, seorang guru memiliki peran sebagai explainer atau pemberi penjelasan. Kemam-puan guru dalam menjelaskan materi secara sistematis, teratur, jelas, menarik perhatian, dan sesuai dengan kompetensi dasar yang ingin dicapai akan mampu membantu siswa dalam memahami pelajaran dengan baik, sehingga akan meningkatkan penghargaan dan rasa percaya siswa terhadap guru. ${ }^{4}$

\footnotetext{
${ }^{2}$ Mukhlison Effendi, Komunikasi Orang Tua Dengan Anak (Keharusan Yang Sering Terabaikan) (Ponorogo: STAIN Ponorogo Press, 2012), 24.

${ }^{3} \mathrm{AW}$, Komunikasi Interpersonal, 22.

${ }^{4}$ Suyono and Hariyanto, Belajar Dan Pembelajaran Teori Dan Konsep Dasar (Bandung: Remaja Rosdakarya, 2014), 2015-2216.
}

Nabi Musa merupakan salah satu utusan Allah sekaligus seorang pendidik bagi umatnya. Hal ini dapat dibuktikan dengan beberapa ayat dalam Alquran yang menjelaskan bahwa Nabi Musa merupakan seorang edukator, di antaranya dapat dilihat dari beberapa ayat berikut ini.

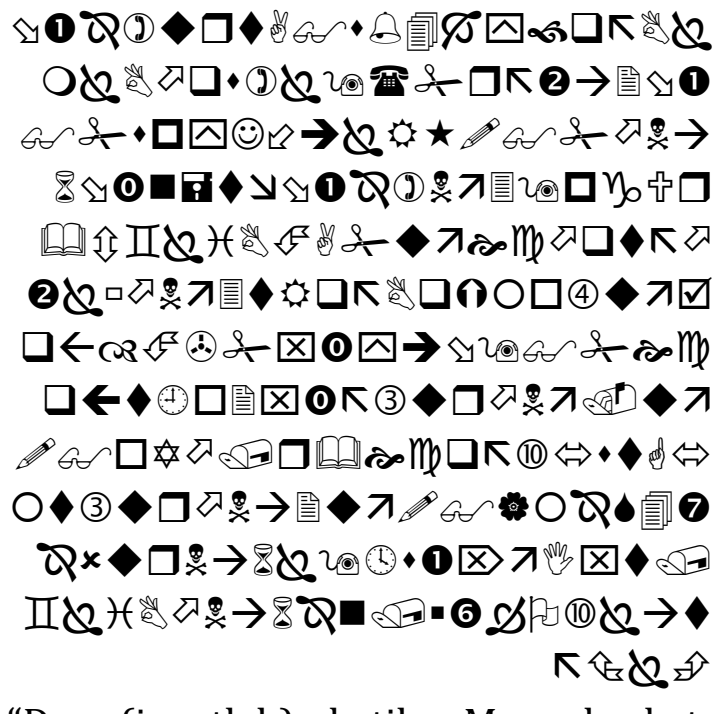

"Dan (ingatlah), ketika Musa berkata kepada kaumnya: "Ingatlah nikmat Allah atasmu ketika Dia menyelamatkan kamu dari (Fir'aun dan) pengikut-pengikutnya, mereka menyiksa kamu dengan siksa yang pedih, mereka menyembelih anak-anak laki-lakimu, membiarkan hidup anakanak perempuanmu, dan pada yang demikian itu ada cobaan yang besar dari Tuhanmu."(QS Ibrahim: 6)

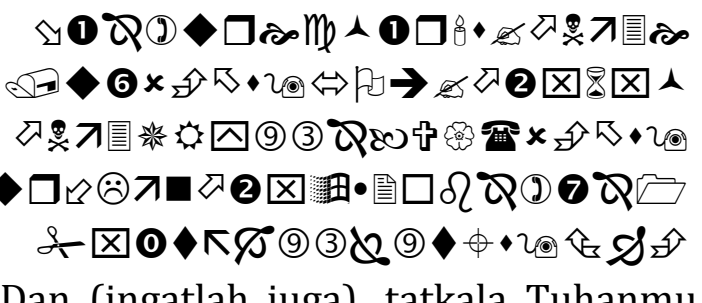
"Dan (ingatlah juga), tatkala Tuhanmu memaklumkan; Sesungguhnya jika kamu bersyukur, pasti Kami akan menambah (nikmat) kepadamu, dan jika kamu mengingkari (nikmat-Ku), 
maka sesung-guhnya azab-Ku sangat pedih."(QS Ibrahim: 7) ${ }^{5}$

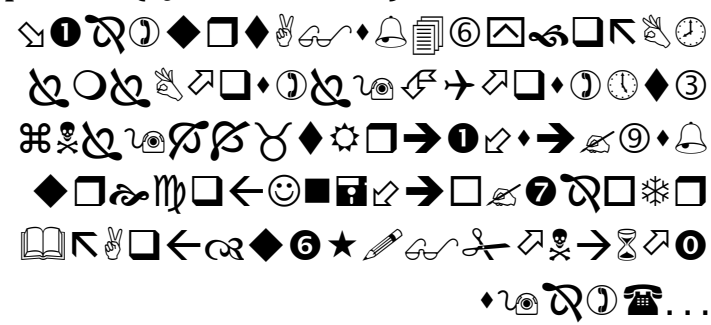

"Dan (ingatlah) ketika Musa berkata kepada kaumnya: "Hai kaumku, mengapa kamu menyakitiku, sedangkan kamu mengetahui bahwa sesungguhnya aku adalah utusan Allah kepadamu?" ... (QS Ash Shaff: 5$)^{6}$

Proses Nabi Musa dalam menyampaikan risalah Allah swt. merupakan kisah yang menarik. Nabi Musa sangat memperhatikan bagaimana cara agar risalah tersebut dapat disampaikan dan diterima dengan baik oleh Bani Israil. Hal ini dibuktikan dengan doa Nabi Musa yang meminta kepa-da Allah agar dipermudah lisannya dalam penyampaian risalah. Nabi Musa juga men-jadikan Harun sebagai saudaranya untuk pendamping dalam dakwahnya karena lebih fasih dalam berbicara dan memiliki budi bahasa yang baik. $^{7}$

$\begin{array}{ccc}\text { Saat } & \text { ini, sebagian besar } & \text { guru } \\ \text { kurang } & \text { memperhatikan } & \text { cara }\end{array}$
berkomunikasi yang baik dengan siswa. Banyak guru yang hanya menyampaikan materi tetapi kurang mem-perhatikan cara penyampaian materi yang baik, sehingga siswa tidak dapat memahami materi yang disampaikan oleh guru.

\footnotetext{
${ }^{5}$ Kementrian Agama RI, "Al-Qur'an Dan Tafsirnya" (Lentera Abadi, 2010), 127.

${ }^{6}$ M. Quraish Shihab, Tafsir Al-Misbah: Pesan, Kesan, Dan Keserasian Al-Qur'an (Jakarta: Lentera Hati, 2003), 193.

${ }^{7}$ Ibid., 344.
}

Nabi Musa merupakan salah satu Rasul Allah yang dapat dijadikan contoh oleh seorang pendidik dalam melaksanakan pembelajaran. Nabi Musa tetap memper-hatikan cara penyampaian risalah dengan baik meskipun memiliki kekuragan. Mes-kipun memiliki kekurangan, seorang pendi-dik harus berusaha melakukan komunikasi dengan baik, sehingga pesan yang disam-paikan dapat diterima dan dipahami dengan baik oleh peserta didik.

Komunikasi berasal dari bahasa Latin,yaitu communis yang berarti umum (common) atau bersama. ${ }^{8}$ Everett $M$. Rogers dalam buku karangan Hafied Cangara me-ngemukakan pengertian komunikasi seba-gai suatu proses mengalihkan ide dari sum-ber kepada satu penerima atau lebih de-ngan maksud untuk mengubah tingkah laku mereka. ${ }^{9}$

Komunikasi edukatif atau komunikasi pendidikan memiliki arti proses perjalanan pesan atau informasi dalam bidang pendidikan demi terwujudnya tuju-an dalam pendidikan tersebut.10 Komu-nikasi guru pada siswa ada dua macam, yaitu komunikasi verbal dan komunikasi nonverbal. Moore dalam buku Dede Rosyada membagi komunikasi verbal untuk proses pembelajaran menjadi dua, yaitu verbal learning dan vocal learning.Verbal learning adalah proses pembelajaran yang dilakukan siswa dengan memahami apa yang disampaikan

\footnotetext{
${ }^{8}$ Tommy Suprapto, Pengantar Teori Komunikasi (Yogyakarta: Media Pressindo, 2006), 5.

${ }^{9}$ Hafied Cangara, Perencanaan Dan Strategi

Komunikasi (Jakarta: Raja Grafindo Persada, 2013), 33.

${ }^{10}$ Effendi, Komunikasi Orang Tua Dengan Anak (Keharusan Yang Sering Terabaikan), 25.
} 
guru melalui kata-kata yang diucapkannya. ${ }^{11}$ Sedangkan vocal learning adalah proses pembelajaran yang dilakukan oleh siswa dengan memahami pesan-pesan yang diucapkan guru dengan memperhatikan tempo dan intonasi suara. Selain menggunakan komunikasi verbal, guru biasanya juga menggunakan komunikasi nonverbal, yakni komunikasi yang tidak menggunakan kata-kata, tidak bisa didengar dan juga tidak bisa dibaca dalam uraian kata-kata tertulis. ${ }^{12}$

Belajar merupakan suatu perubahan yang terjadi melalui latihan atau penga-laman. ${ }^{13}$ Belajar merupakan suatu proses yang dapat mengubah sikap, tingkah laku, dan pengetahuan kita. ${ }^{14}$ Menurut Makmun dalam buku Iskandar, proses pembelajaran merupakan suatu interaksi antara guru dengan siswa dalam rangka mencapai tuju-annya. ${ }^{15}$ Dengan demikian, belajar itu sifat-nya mengikat antara kedua belah pihak yang bertujuan untuk mengubah sikap, ting-kah laku, dan pengetahuan.

M. Ngalim Purwanto membagi tujuan pendidikan dan pengajaran menjadi empat, yaitu tujuan umum, tujuan institusional, tujuan kurikuler, dan tujuan instruksional. 16

Dalam pembelajaran juga terdapat strategi. Strategi adalah suatu rancangan

\footnotetext{
${ }^{11}$ Dede Rosyada, Paradigma Pendidikan Demokrasi, Sebuah Model Pelibatan Masyarakat Dalam Penyelenggaraan Pendidikan (Jakarta: Kencana, 2007), 148.

${ }^{12}$ Ibid., 149.

${ }^{13}$ M. Ngalim Purwanto, Psikologi Pendidikan (Bandung: PT Rosdakarya, 2007), 85.

${ }^{14}$ Ibid., 87.

${ }^{15}$ Iskandar, Psikologi Pendidikan Sebuah Orientasi Baru (Jakarta: Referensi, 2012), 100.

${ }^{16}$ M. Ngalim Purwanto, Ilmu Pendidikan Teoritis Dan Praktis (Bandung: Remaja Rosdakarya, 2009), 40-42.
}

yang sengaja dibuat untuk mengubah tingkah laku melalui transfer ide-ide baru. ${ }^{17}$ Strategi komunikasi edukatif adalah suatu perencanaan yang sengaja dibuat oleh guru atau pendidik agar pesan dan informasi yang disampaikan dalam pembelajaran dapat diterima secara efektif oleh peserta didik, sehingga tujuan pembelajaran dapat tercapai.

Macam-macam model perencanaan yang dapat digunakan guru antara lain dijelaskna di bawah ini. ${ }^{18}$

1. Model perencanaan komunikasi oleh Cultid dan Center

Langkah-langkahperencanaan komunikasi model ini dimulai dengan penemuan fakta (fact finding), kemudian perencanaan (planning), selanjutnya komunikasi (commmunication).

2. Model perencanaan komunikasi oleh Philip Lesly

Model ini memiliki enam tahapan dalam pelaksanaannya, yaitu(a)analisis dan riset, (b)perumusan kebijakan, (c)perencanaan program pelaksanaan, (d)kegiatan komunikasi, (e)umpan balik, dan (f) evaluasi.

3. Model perencanaan komunikasi lima langkah

Model komunikasi ini terdiri ataslima langkah, yaitu: penelitian (research), perencanaan (plan), pelaksanaan (execute), pengukuran (measure), pelaporan (report).

4. Model perencanaan komunikasi oleh John Middleton

Model komunikasi ini memiliki tahapan pengumpulan data baseline dan

\footnotetext{
${ }^{17}$ Cangara, Perencanaan Dan Strategi Komunikasi, 61.

${ }^{18}$ Ibid., 68-85.
} 
need assessment; perumusan tujuan komunikasi; analisis perncanaan dan pengembangan strategi; analisis dan segmentasi khalayak; pemilihan media, desain, dan pengem-bangan pesan; perencanaan manajemen, pelaksanaan pelatihan, implementasi atau pelaksanaan, dan evaluasi program.

5. Model perencanaan komunikasi untuk advokasi

Model komunikasi ini terdiri atas enam langkah, yaitu analisis, strategi, mobi-lisasi, aksi, evaluasi, dan kesinambungan.

6. Strategi komunikasi menurut Stephen Covey $^{19}$

Strategi ini terdiri atas langkah proaktif, merencanakan sesuatu dengan tuntas dalam pikiran, membuat prioritas, berpikir menang-menang, memahami, sinergi, dan memanfaatkan aset yang dimiliki.

Komunikasi adalah suatu proses dan suatu kegiatan yang berlangsung kontinu. Keefektifan suatu komunikasi dapat di-pengaruhi oleh beberapa faktor, yaituthe act (perbuatan), the scene (adegan), the agent (pelaku), the agency (perantara), dan the purpose (tujuan). ${ }^{20}$

Suprapto menyebutkan bahwa Grace danThoha membagi tujuan komunikasi menjadi empat, yaitutujuan fungsional, tujuan manipulasi, tujuan keindahan, dan tujuan keyakinan. ${ }^{21}$

Tidak semua komunikasi dapat berjalan sesuai dengan harapan. Hal ini dapat dipengaruhi oleh beberapa faktor,

\footnotetext{
${ }^{19}$ Muhammad Mufid, Etika Dan Filsafat Komunikasi (Jakarta: Kencana Prenada Media Group, 2009), 132 35.

${ }^{20}$ Suprapto, Pengantar Teori Komunikasi, 7-8.

${ }^{21}$ Ibid., 8-9.
}

berikut ini adalah macam-macam gangguan komunikasi menurut Muhammad Mufid: gangguan komunikasi, kepentingan (inte-rest), dan prasangka. ${ }^{22}$

Berdasarkan latar belakang tersebut, peneliti tertarik untuk melakukan pene-litian dengan judul "Komunikasi Edukatif dalam Perspektif Alquran (Analisis Kisah Musa)". Permasalahan pokok yang dikaji dalam penelitian ini adalah

deksripsikomunikasi edukasi yang terjadi dalam kisah Musa;(2) tahapan strategi komuni-kasi edukasi yang digunakan dalam kisah Musa;dan (3) relevansi tahapan komuni-kasi edukasi yang ada dalam kisah Musa tersebut dengan tahapan komunikasi edukasi yang ada sekarang ini.

Manfaat penelitian ini secara teoritis adalah untuk kontribusi ilmiah bagi pendidikan Islam serta memberikan pemahaman bahwa Alquran mengandung tuntunan dalam berperilaku yang harus diamalkan dalam kehidupan.Secara praktis, bagi pene-liti, penelitian ini untuk menambah keil-muan tentang komunikasi, khususnya ko-munikasi yang baik yang terkandung dalam Alquran. Bagi pembaca, penelitian ini digu-nakan sebagai sarana belajar mengambil hikmah di balik sebuah kejadian atau kisah-kisah yang telah terjadi pada peristiwa tersebut.

\section{B. METODOLOGI PENELITIAN}

Pendekatan yang digunakan dalam penelitian ini adalah pendekatan historis. Pendekatan historis digunakan untuk memahami suatu peristiwa dilihat dari

\footnotetext{
${ }^{22}$ Mufid, Etika Dan Filsafat Komunikasi, 144.
} 
konteks historisnya. ${ }^{23}$ Jenis penelitian ini menggu-nakan penelitian library research yaitu penelitian yang dilakukan dengan cara membaca buku-buku dan sumber lainnya yang ada di perpustakaan. ${ }^{24}$

Sumber data dalam kajian ini berasal dari berbagai literatur kepustakaan yang mempunyai relevansi dengan masalah ko-munikasi edukatif dalam perspektif Alquran (khususnya analisis isah Nabi Musa).

Teknik pengumpulan data dalam penelitian ini adalah teknik dokumentasi. Teknik dokumentasi adalahcara mengumpulkan data dengan menghimpun dan menganalisis dokumen, baik dokumen tertulis maupun tidak tertulis. ${ }^{25}$ Data-data yang diperoleh dianalisis dengan menggunakan analisis isi (content analysis) yaitu teknik sistematis yang digunakan untuk menganalisis isi pesan, mengolah pesan, atau untuk mengobservasi dan menganalisis perilaku komunikasi. ${ }^{26}$

\section{HASIL DAN PEMBAHASAN}

\section{Analisis Komunikasi Edukatif dalam} Kisah Musa

Komunikasi edukatif merupakan proses perjalanan pesan dalam dunia pendidikan demi terwujudnya tujuan pendidikan tersebut. Sebagaimana telah diutarakan oleh Ngalim Purwanto bahwa seseorang dikatakan telah belajar apabila terjadi perubahan pada sikap, tingkah

23 Abudin Nata, Metodologi Studi Islam (Jakarta: Raja Graffindo Persada, 1998), 48.

${ }^{24}$ Mahmud, Metode Penelitian Pendidikan (Bandung: Pustaka Setia, 2011), 31.

${ }^{25}$ Nana Syaodih Sukmadinata, Metode Penelitian

Pendidikan (Bandung: Remaja Rosdakarya, 2009), 221-22.

${ }^{26}$ Amirul Hadi and Haryono, Metodologi Penelitian

Pendidikan (Bandung: Pustaka Setia, 1998), 175. laku, dan pengetahuannya. Komunikasi dalam proses pembelajaran tidak hanya bertujuan untuk meningkatkan pemahaman dari tidak tahu menjadi tahu, tetapi juga mengubah sikap dan tingkah laku peserta didik sesuai dengan kompetensi yang ingin dicapai. ${ }^{27}$

Dalam kisah Musa, komunikasi edukatif terdapat padaperistiwa ketika para penyihir Fir'aun masuk ke dalam ajaran Islam. Dalam komunikasi ini Musa berperan sebagai komunikator yang menyampaikan pesan dan edukator dalam proses pembelajaran. Musa menyampaikan dakwah kepada Fir'aun setelah menerima wahyu dan mendapat perintah untuk meng-hentikan kekejaman yang dilakukan oleh Fir'aun. Wahyu pertama yang diterima oleh Musa adalah perintah untuk menyampaikan dan menanamkan agama tauhid kepada Bani Israil, sebagaimana firman Allah di bawah ini.

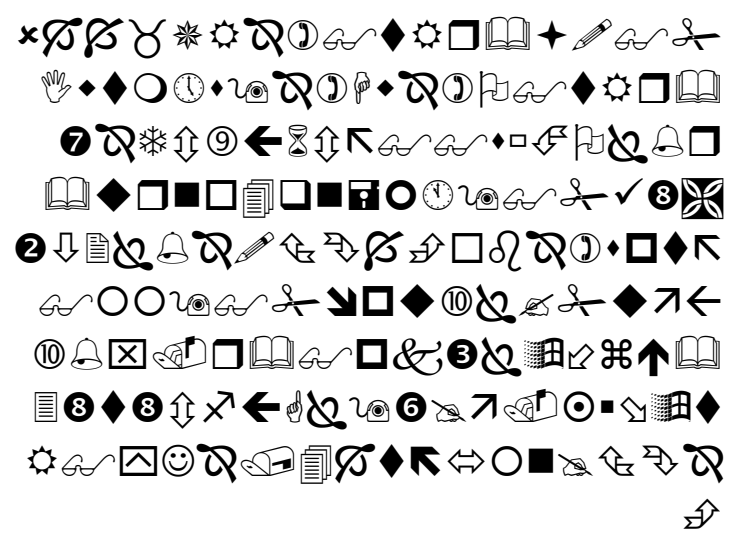

"Sungguh, Aku ini adalah Allah, tidak ada Tuhan (yang hak) selain Aku, Maka sembahlah Aku dan laksanakanlah shalat untuk mengingat Aku."

"Sesungguhnya hari kiamat itu akan datang, Aku merahasiakan (waktunya)

${ }^{27}$ Purwanto, Psikologi Pendidikan, 85. 
agar tiap-tiap diri itu dibalas dengan apa yang ia usahakan." (QS Thaha: 14-15)28

Telah dijelaskan sebelumnya bahwa komunikasi edukatif memiliki tujuan untuk mengubah pengetahuan, sikap, dan juga tingkah laku. Pengajaran tauhid yang dila-kukan Nabi Musa kepada Bani Israil pada dasarnya dilatarbelakangi oleh adanya penyembahan yang dilakukan Bani Israil kepada Fir'aun. Hal ini menandakan adanya ketidaktahuan mereka tentang hakikat ketuhanan dengan melaksanakan apa yang diperintahkan Fir'aun kepada mereka.

Dengan demikian, komunikasi yang terjadi dalam kisah Musa merupakan komu-nikasi edukatif yang dapat dilihat dari peran Nabi Musa sebagai seorang edukator yang menyampaikan pesan mengenai ajaran ketauhidan kepada Bani Israil dengan tujuan mengubah pengetahuan Bani Israil tentang ketauhidan dan menanamkan kei-manan dalam hati mereka, sehingga mereka selalu menghindari perbuatan keji dan munkar.

\section{Analisis Tahapan Komunikasi Edukatif dalam Kisah Musa}

Komunikasi dalam pembelajaran memiliki tujuan agar informasi atau pesan yang disampaikan oleh guru atau pendidik dapat diterima dengan efektif oleh peserta didik. ${ }^{29}$ Tujuan dari komunikasi yang dilakukan Nabi Musa adalah untuk mengajarkan tauhid dan menghentikan kekejaman Fir'aun, sebagaimana terdapat dalam QS Thaha ayat 4 .

\footnotetext{
${ }^{28}$ Kementrian Agama RI, “Al-Qur'an Dan Tafsirnya," 119.

${ }^{29} \mathrm{AW}$, Komunikasi Interpersonal, 27.
}

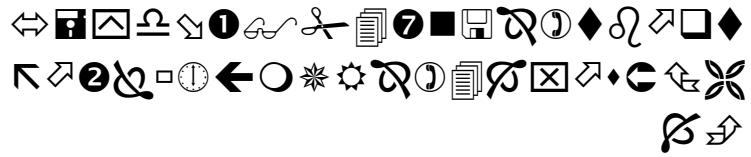

"Pergilah kepada Fir'aun; Sesungguhnya ia telah melampaui batas."30

Dan dalam surat Ibrahim ayat 5:

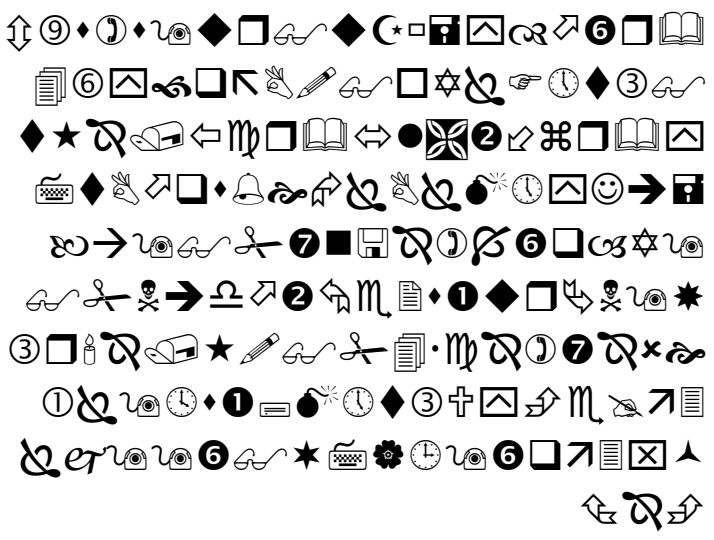

"Dan sesungguhnya Kami telah mengutus Musa dengan membawa ayat-ayat Kami, (dan Kami perintahkan kepadanya): "Keluarkanlah kaummu dari gelap gulita kepada cahaya terang benderang dan ingatkanlah mereka kepada hari-hari Allah". Sesunguhnya pada yang demikian itu terdapat tanda-tanda (kekuasaan Allah) ba-gi setiap orang penyabar dan banyak bersyukur."31

Nabi Musa memohon untuk menjadikan Harun sebagai saudaranya. Permintaan Nabi Musa ini memiliki tujuan agar pesan yang disampaikan dapat dipahami dan diterima dengan baik oleh Bani Israil. Nabi Musa memiliki kekurangan pada lidahnya, sehingga dengan adanya Harun diharapkan dapat menutupi kekurangan yang ada pada dirinya dan dapat menjadi penguat dalam setiap hujjah-hujjah yang disampaikan oleh Nabi Musa.

\footnotetext{
${ }^{30}$ Kementrian Agama RI, "Al-Qur'an Dan Tafsirnya," 128.

${ }^{31}$ Ibid., 127.
} 
Nabi Musa dan Harun sempat merasa takut untuk menghadapi Fir'aun, sehingga Allah berfirman,

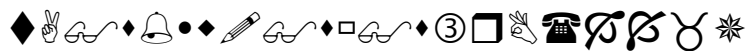

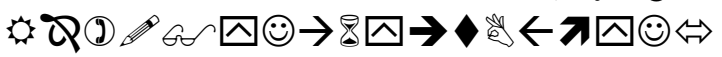

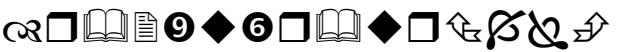

"Janganlah kamu berdua khawatir, sesungguhnya Aku beserta kamu berdua, Aku mendengar dan melihat."32

Allah meminta Nabi Musa dan Harun untuk menghilangkan ketakutan yang ada pada diri mereka dan memerintahkan agar tetap optimis dalam menjalankan tugasnya karena Allah akan selalu bersama mereka.

Nabi Musa dan Harun pergi kepada Fir'aun dengan membawa ayat-ayat dan mukjizat yang dianugerahkan kepadanya. Allah memberikan peringatan kepada Nabi Musa bahwa dalam penyampaian pesan harus dengan lemah lembut. Dalam komunikasi ini terjadi tanya jawab antara Nabi Musa dengan Fir'aun sebagaimana yang terdapat di QS Thaha ayat 49-55. Tanya jawab ini dimulai dengan pertanyaan yang diajukan oleh Fir'aun kepada Nabi Musa. Nabi Musa tidak membantah semua pertanyaan yang diajukan Fir'aun, melainkan memberikan kesempatan kepada Fir'aun dan memberikan jawaban secara bijaksana.Dalam komunikasi ini masih terjadi kega-galan disebabkan oleh prasangka yang timbul dalam diri Fir'aun dan para pengi-kutnya yang menganggap bahwa Nabi Musa telah melakukan sihir dan meminta Nabi Musa untuk melakukan pertandingan de-ngan para penyihir Fir'aun.

Sebelum pertandingan dimulai, Nabi Musa mengingatkan mereka dengan ancam-an-ancaman yang bertujuan untuk menim-bulkan rasa takut pada diri penyihir Fir'aun dan berharap mereka mau beriman kepada Allah. Nabi Musa menggunakan dua muk-jizat yang dibawanya sebagai media untuk mematahkan tuduhan bahwa dia telah menggunakan sihir.

Para penyihir Fir'aun menyatakan tunduk dan beriman setelah mendengarkan ancaman dan bukti yang ditunjukkan oleh Nabi Musa. Sikap atau tingkah laku yang ditimbulkan merupakan umpan balik dalam komunikasi. Sikap mereka yang tunduk kepada Nabi Musa merupakan umpan balik dari komunikasikomunikasi yang telah dilakukan oleh Nabi Musa.

Peristiwa penyembahan lembu bermula ketika Samiri membuat anak lembu dari perhiasan emas kemudian dia memasukkan segenggam tanah yang dia ambil dari jejak Rasul, sehingga anak lembu terse-but dapat berbunyi sebagaimana lembu sebenarnya. Peristiwa ini merupakan coba-an yang diberikan Allah kepada Bani Israil untuk mengetahui kebenaran keimanan me-reka, apakah mereka benar-benar beriman atau keimanan mereka hanya di bibir saja. Sebagaimana firman Allah dalam QS Al'Ankabut ayat 2-3.

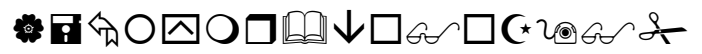

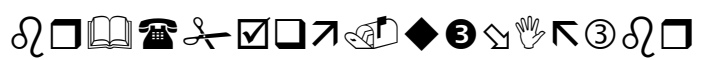

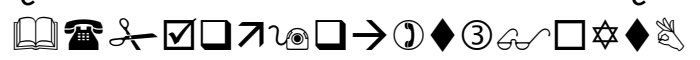

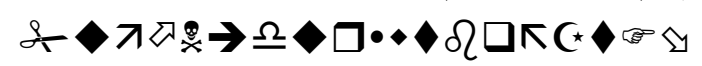

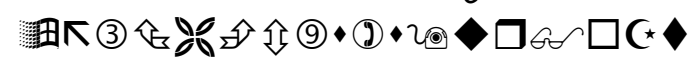

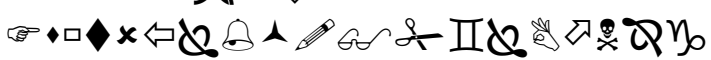

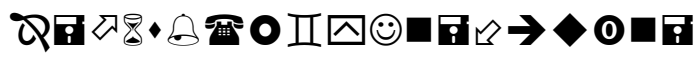

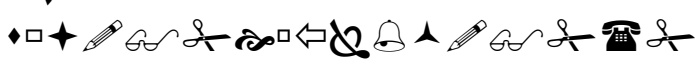

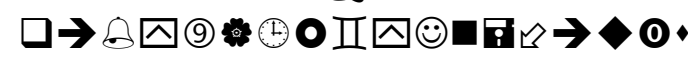

\footnotetext{
${ }^{32}$ Ibid., 141.
} 


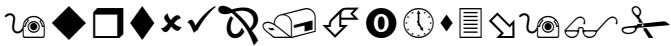
它舟金

"Apakah manusia itu mengira bahwa mereka dibiarkan (saja) mengatakan: "Kami telah beriman", sedang mereka tidak diuji lagi?"

"Dan Sesungguhnya Kami telah menguji orang-orang yang sebelum mereka, Maka Sesungguhnya Allah mengetahui orangorang yang benar dan Sesungguhnya Dia mengetahui orang-orang yang dusta."33

Allah tidak akan membiarkan seseorang mengatakan telah beriman tanpa memberikan ujian terlebih dahulu. Setiap orang beriman harus diuji terlebih dahulu, sehingga diketahui sampai dimanakah mereka sabar dan tahan menerima ujian tersebut. Orang-orang yang beriman akan tetap berpegang teguh dengan keimanannya dalam menghadapi ujian tersebut. Demikian Allah menguji keimanan Bani Israil yang menyatakan beriman dan akan tetap beriman walaupun ditinggalkan oleh Nabi Musa.

\section{Relevansinya dengan Tahapan Strategi Komunikasi Edukatif}

Di atas telah dijelaskan bahwa Nabi

Musa menggunakan perencanaan atau stra-tegi dalam penyampaian pesan agar Bani Israil dapat memahami dan menerima seca-ra efektif pesan yang disampaikan. Komu-nikasi yang akan dilakukan harus direnca-nakan dengan sistematis disesuaikan de-ngan kondisi dan situasi komunikan. Hal ini juga berlaku bagi seorang guru dalam menyampaikan pesan atau materi pelajaran kepada siswa dengan baik, sehingga tujuan pembelajaran dapat

\footnotetext{
${ }^{33}$ Ibid., 156.
}

tercapai. Dengan demi-kian dapat diketahui bahwa ada relevansi antara strategi komunikasi edukatif yang terdapat dalam kisah Musa dengan strategi komunikasi edukatif yang ada sekarang ini.

Hubungan antara strategi komunikasi dalam kisah Musa dengan strategi komunikasi yang ada sekarang ini dapat dijelaskan melalui tahapan-tahapan perencanaan sebagai berikut.

Penemuan masalah merupakan akar dan alasan komunikasi akan dilakukan, se-hingga dapat ditetapkan tujuan komunikasi dan cara untuk mewujudkan tujuan terse-but. Dalam kisah Musa, penemuan masalah berkedudukan sebagai latar belakang atau alasan perintah untuk mengajarkan tauhid. Dalam pendidikan, penemuan masalah dapat dijadikan sebagai acuan guru dalam menentukan tujuan pembelajaran yang akan dilakukan. Langkah dalam kisah Musa ini memiliki relevansi dengan model peren-canaan komunikasi Cultid dan Center (ta-hap penemuan fakta) dan model peren-canaan lima langkah (tahap penelitian) yang menjadikan masalah sebagai hal perta-ma yang harus diketahui dalam suatu perencanaan komunikasi.

Tujuan merupakan langkah kedua setelah menemukan masalah. Dalam kisah Musa tujuan dari komunikasi yang akan dilakukan diterangkan melalui wahyu. Dalam pendidikan, tujuan suatu pembelajaran dapat diturunkan melalui silabus kemudian silabus tersebut diturunkan ke dalam tuju-an yang lebih terperinci yang tersusun da-lam SK, KD, dan indikator. Langkah ini memiliki 
relevansi dengan model peren-canaan John Middleton, sedangkan dalam model perencanaan yang lain meletakkan tujuan dalam langkah perencanaan.

Nabi Musa memberikan contoh bah-wa dalam suatu komunikasi diperlukan perencanaan yang matang. Penetapan wak-tu pelaksanaan yang tepat, teknik yang akan digunakan, pesan yang akan disampaikan, serta pemanfaatan aset sebagai media komunikasi sangat menentukan keber-hasilan dari suatu komunikasi. Pemanfaatan media harus disesuaikan dengan situasi dan kondisi komunikan. Langkah ini memiliki relevansi dengan model perencanaan Cultid dan Center, Philyp Lesly, lima langkah, John Middleton, dan advokasi.

Mengenai pelaksanaan komunikasi, Nabi Musa menggunakan teknik tanya jawab. Dalam komunikasi pembelajaran harus terjadi proses interaksi antara guru dan murid. Tahap ini memiliki relevansi dengan model perencanaan Cultid dan Center, Philip Lesly, lima langkah, John Middleton, dan advokasi yang meletakkan pelaksanaan sebagai kegiatan yang dilakukan setelah perencanaan.

Umpan balik merupakan hal yang penting dalam komunikasi karena melalui tanggapan dan tingkah laku dari komunikan akan memperlihatkan keberhasilan dari komunikasi yang telah dilakukan. Umpan balik yang ditampilkan dapat bersifat positif (menerima) dan negatif (penolakan). Jika siswa menunjukkan sikap yang sesuai dengan tujuan yang diharapkan, maka dapat berarti bahwa mereka memahami pesan yang telah disampaikan oleh guru. Sebaliknya, jika siswa belum menampilkan sikap dan tingkah laku yang sesuai dengan harapan, maka guru harus merancang kembali strategi dengan memperhatikan hambatan yang mengakibatkan kegagalan dalam komunikasi agar siswa dapat mema-hami pesan yang disampaikan. Tahap ini memiliki relevansi dengan model peren-canaan Philip Lesly yang meletakkan umpan balik sebagai suatu hal yang harus ada dalam perencanaan komunikasi.

Tahapan terakhir dalam suatu perencanaan adalah evaluasi. Evaluasi dalam kisah Musa diberikan kepada Bani Israil melalui cobaan yang diberikan Allah kepada mereka untuk menguji keimanan mereka. Evaluasi digunakan untuk mengukur ting-kat keberhasilan strategi yang telah dilaksa-nakan. Dalam pendidikan, evaluasi harus dilakukan untuk mengetahui tingkat penca-paian siswa setelah pembelajaran dalam memenuhi standar kompetensi yang telah ditentukan. Tahap ini memiliki relevansi dengan model perencanaan Philip Lesly, lima langkah, John Middelton, dan advokasi.

Dengan demikian, dapat diketahui bahwa tahapan strategi komunikasi edukatif dalam kisah Musa merupakan gabungan dari bebe-rapa tahapan dalam strategi komunikasi Cultid dan Center, Philip Lesly, John Middleton, lima langkah, dan advokasi.

\section{PENUTUP}

Berdasarkan hasil analisis data dan pembahasan, dapat disimpulkan sebagai berikut.

1. Komunikasi yang terjadi dalam kisah Musa merupakan komunikasi edukatif 
yang dapat dilihat dari peran Nabi Musa sebagai seorang edukator yang menyam-paikan pesan kepada Bani Israil dan tujuan komunikasi tersebut yaitu meng-ubah pengetahuan Bani Israil tentang ketauhidan dan menanamkan keimanan dalam hati mereka, sehingga mereka selalu menghindari perbuatan keji dan munkar.

2. Tahapan-tahapan yang terdapat dalam strategi komunikasi edukatif dalam kisah Musa meliputi kegiatan menemukan masalah yang sedang dihadapi Bani Israil, menentukan tujuan melalui pene-rimaan wahyu, merencanakan komuni-kasi, menyampaikan risalah, umpan balik, dan evaluasi berupa cobaan yang diturunkan oleh Allah kepada Bani Israil.

3. Tahapan strategi komunikasi edukatif dalam kisah Musa merupakan gabungan dari beberapa tahapan strategi komunikasi Cultid dan Center, Philip Lesly, John Middleton, lima langkah, dan advokasi. Tahapan tersebut meliputi penemuan masalah (Cultid dan Center (tahap penemuan fakta) dan model perencanaan lima langkah (tahap penelitian)), merumuskan tujuan (John Middleton), perencanaan (model perencanaan Cultid dan Center, Philyp Lesly, lima langkah, John Middleton, dan advokasi), membentuk kerja sama komunikasi (Stephen Covey), pelaksanaan (model perencanaan Cultid dan Center, Philip Lesly, lima langkah, John Middleton, dan advokasi), umpan balik (Philip Lesly), dan evaluasi (Philip
Lesly, lima langkah, John Middelton, dan advokasi).

Dalam Alquran masih banyak tahap perencanaan strategi komunikasi edukatif secara sistematis dan teknik komunikasi yang dapat digunakan dalam pembelajaran masa kini, sehingga perlu diadakan pene-litian lebih lanjut terutama dalam kisah-kisah edukatif yang ada di dalam Alquran.

Semoga penelitian ini dapat bermanfaat dan dapat dijadikan bahan rujukan, refleksi, maupun perbandingan untuk ka-jian di masa selanjutnya khususnya dalam mengembangkan perencanaan strategi dan teknik komunikasi edukatif yang ada dalam Alquran yang dapat digunakan sebagai pedoman dalam pembelajaran.

\section{E. DAFTAR PUSTAKA}

AW, Suranto. Komunikasi Interpersonal. Yogyakarta: Graham Ilmu, 2011.

Cangara, Hafied. Perencanaan Dan Strategi Komunikasi. Jakarta: Raja Grafindo Persada, 2013.

Effendi, Mukhlison. Komunikasi Orang Tua Dengan Anak (Keharusan Yang Sering Terabaikan). Ponorogo: STAIN Ponorogo Press, 2012.

Hadi, Amirul, and Haryono. Metodologi Penelitian Pendidikan. Bandung: Pustaka Setia, 1998.

Iskandar. Psikologi Pendidikan Sebuah Orientasi Baru. Jakarta: Referensi, 2012.

Kementrian Agama RI. "Al-Qur'an Dan Tafsirnya." Lentera Abadi, 2010.

Mufid, Muhammad. Etika Dan Filsafat Komunikasi. Jakarta: Kencana Prenada Media Group, 2009. 
Purwanto, M. Ngalim. Ilmu Pendidikan

Teoritis Dan Praktis. Bandung: Remaja Rosdakarya, 2009.

Psikologi Pendidikan. Bandung: PT Rosdakarya, 2007.

Rosyada, Dede. Paradigma Pendidikan Demokrasi, Sebuah Model Pelibatan Masyarakat Dalam Penyelenggaraan Pendidikan. Jakarta: Kencana, 2007.

Shihab, M. Quraish. Tafsir Al-Misbah: Pesan, Kesan, Dan Keserasian AlQur'an. Jakarta: Lentera Hati, 2003.

Sukmadinata, Nana Syaodih. Metode Penelitian Pendidikan. Bandung: Remaja Rosdakarya, 2009.

Suprapto, Tommy. Pengantar Teori Komunikasi. Yogyakarta: Media Pressindo, 2006.

Suyono, and Hariyanto. Belajar Dan Pembelajaran Teori Dan Konsep Dasar. Bandung: Remaja Rosdakarya, 2014. 